UDC: 378

\title{
THE ROLE OF EDUCATION IN SUSTAINABLE DEVELOPMENT
}

\author{
T. P. Golub \\ Kyiv, National Technical University of Ukraine "Kyiv Polytechnic Institute" \\ ukraine.golub@gmail.com
}

\begin{abstract}
The article is devoted to the study of education as a factor and a mean of sustainable development of the modern society. The concept of sustainable development is segregated and viewed by many scientists from all over the world as perhaps the only real promising possibility of stable development of mankind in contemporary challenges and crises. The common feature of the approaches developed to understanding and putting into practice the concept of sustainable development is technotronic and operational orientation to the metaphysical science project, concluding that all the pressing global problems can be solved within the framework of technotronic-manipulative techniques in the field of economics, management, development of new technologies, including biological, et al. The crisis of education and changes in social and cultural life of a mankind are closely interconnected, they strengthen and stipulate each other. Here the leading role is played by the social and philosophical idea that the education system not only reflects the productive and social and political life of the society, but can be an important or even decisive factor of its change, its entering the path of sustainable development. Taking education as a factor in the adaptation of society to the sustainable development should be the main methodological principle of the reviving strategy globally. Global education is a special metasystem, where the aims of the world education policy for the solution of global problems are defined and implemented, where specific ties and relations between states and their educational systems aimed at all-round empowerment of the most effective forms of implementation of tasks of the future are operated.
\end{abstract}

Key words: sustainable development, education, global education area, society.

Introduction. The urgency of proper social and philosophical study of education as a factor for sustainable development provision of the society is caused by to the fact that the system of education determines the understanding of both axiology of modern education, the ability to influence the formation of spiritual and moral priorities of the individual and the updating of the stable social development strategy in the $21^{\text {st }}$ century.

In modern conditions the search for alternative ways of social development, the problem of consciousness in all its multidimensional adaptation of society to the new reality is ranked among the most urgent. The concept of sustainable development is segregated and viewed by many scientists from all over the world as perhaps the only real promising possibility of stable development of mankind in contemporary challenges and crises.

Education posesses the main part in the process since it gives not only professional skills, but also lays the foundations of praxeology and axiology, mental and spiritual patterns, reproduces sociality as a set of mental and cognitive behavioral programs, and mental abilities and cultural activities of a person.

Nowadays the study of education as a major factor of sustainable development of the society and its adaptation to changes is the most relevant, because such education provides the adaptive capacity of the society at its different structure levels by training and education of new generations through the outlook, culture and knowledge, which are formed by the interaction and realized in the direction of social development.

All these leads to a special urgency of social and philosophical analysis of education as a factor for sustainable development of society, which requires a joint study of conceptual ideas of education, as well as the concept of sustainable development of the society both globally and at the level of a single country, particularly, Ukraine.

Ukrainian and foreign scholars have different opinions regarding the understanding of education and its role in social development, as well as as for the interaction of society and nature. In general, these studies are conceptualized as a part of the methodology of modern education.

Social and philosophical understanding of education as an adaptive mechanism of society is impossible without the influence of a number of rapidly developing trends of global scale. The social role of education involves not only the transfer of a pragmatic set of "Left Behind" knowledge, skills and functions, but also the raise of certain personal qualities (commitment, intelligence, philosophy, 
responsibility, activity, creativity), moral guidelines, aimed at the future, in order to give an opportunity to successfully fit into the evolving structure of social and economic relations.

In the second half of the $20^{\text {th }}$ - early $21^{\text {st }}$ century the profound changes in almost all the levels of social life have taken place in a result of previous social and historical development of mankind. In this regard the most important nowadays is the study of the processes of human adaptation to a world based on knowledge through cognitive mechanisms as well as the explication of the function of social cognitive adaptation to the modern society of real and potential supernatural world.

Under these conditions, the question of a new understanding of the mission, possition, nature, and functions of the entire educational sphere as a system of stabilization of the society and at the same time as a mean of its "designing"; and a new position of a person in the education system, where a person is the main reason as well as the main consequence of changes, becomes the most important at the situation of crossroads of adaptation processes of the human community aside degradation or development.

The aim of the paper is to study the place and the role of education as a factor for sustainable development of modern society.

Urgency of the research. Year 2005 is the year of the decade, the United Nations declared the decade of Education for Sustainable Development beginning. "Sustainable development meets the needs of the present without compromising the world for future generations. But how do we teach this?" is asked in the epigraph to the Newspaper of UNESCO's Education Sector "Education Today" named "Educating for tomorrow's world", which is devoted to the problems of education for sustainable development [1]. Peter Smith, Assistant Director-General for Education, UNESCO, points out that the answer to this question is both simple and complex. At first glance, it is obvious that the aim of such education is "just" to learn to make the world better for us and for future generations, the complexity of achieving this target is caused by the need to consider economic, social, civil and cultural perspectives. It is obvious that traditional "disciplinary" principle of education (it is the principle the vast majority - if not all - specialists are trained in Ukraine) is hardly compatible with the objectives of education for sustainable development. The most proper considers the principle of "learning-by-doing" which requires the development of adequate models of communicative practices with taking into account the interaction between different spheres of social, age and ethnic groups as well as the inevitable interdisciplinarity.

According to the scientific analysis, this problem is urgent in the world. Its solution depends on the feasibility of an integrated approach to consideration of issues such as the problem of interdisciplinarity in studies, "active" forms of learning (cooperative learning, project learning, etc.) and inclusive approaches in education.

The thing is that sustainable development is possible only if its ideas become the part of consciousness of every person. First of all, it means that it is urgent to overcome the most ancient of human stereotypes - the stereotype of dividing the world into self and others; as well as overcome social stereotypes. Here a large, if not a decisive role belongs to the speech, and the main areas designed to bring it to consciousness of people is the mass media and the system of education, including formal and informal education. Implementation of the stereotype "self - others" is manifested in opposition of self subject knowledge as knowledge of the primary, true, important; and interdisciplinary knowledge as derived, ephemeral, unimportant (and even harmful) knowledge. Such a vision results in an underdeveloped interdisciplinary training, irrelevant specialties and programs, in the absence of effective mechanisms of implementation of interdisciplinary ties.

The stereotype "self - others" prevents the spread of outward-oriented active learning and results in the contraction of the professional and civil liability and their uncorrelation with the tasks facing modern society, the most important of which is sustainable development. World practice solves this problem by developing versatile partnership, involving educational organizations, as well as implementing the concept of learning communities and learning regions.

Global crises of human development can not be overcome only with the help of technotronic means and methods (technical, technological, economic, managerial etc.), it is topical to change the mentality of people, their ideological and axiological life imperatives. It is reasonable that in these circumstances the attention of scientists is attracted by the problem of adaptation not only of the whole 
society on a global scale, but also of individual countries and social institutions, as well as certain social groups, especially young generation.

The crisis of education and changes in social and cultural situation are closely interconnected, they strengthen and stipulate each other. Indeed, earlier in historical retrospect education provided continuous transmission of cultural universals from generation to generation. Nowadays, in the upcoming conditions of total alienation of a human, the forms of modern education are caused by such alienation, and they do not provide any methods and means to overcome and adapt that is related to the installation of the global context. In other words, the awareness of the causes of the crisis in education and the search for the mechanisms of adaptation to modern society are closely linked to changes.

Dialectical approach to the problems of society and education adaptation can be specified by means of cybernetic epistemology in the way of simulation models development that can not only clarify the current understanding of the adaptation, in a way adequate to public consciousness of the modern world, but have the scientific and heuristic value as well. Science and heuristic value of these models is defined by the fact that they allow us to identify not only common features in the specifics of dialectical interaction between education and society, but also special features, for instance, the types of feedback and their hierarchy. This dialectics of the universal and the particular is manifested in the fact that the adaptation of society's problems to be solved (or that should be solved) by means of education has a global nature i.e. is universal, though it is manifested in actions and minds of each single person. At the same time, the level of special (region) is an intermediate level, by means of which the relationships between the universal (global) and specific (each person) are caused [3].

Concept analysis. The concept "sustainable development" is the result of the prolonged research of scientists on the problem of how to avoid the possibility of environmental shocks, the emergence and development of which was noticeable in the way of further expansion of the economy of market fundamentalism. The common feature of the approaches developed to understanding and putting into practice the concept of sustainable development in different countries is technotronic and operational orientation to the metaphysical project, concluding that all the pressing global problems can be solved within the framework of technotronic-manipulative approach in the field of economics, management, development of new technologies, including biological, et al.

The analysis of the concept of sustainable development should be carried out within the framework of distinction between the two systems of theorizing (metaphysical and dialectical), since the very emergence of the modern crisis is a consequence of a fundamentalist following to one of these projects, precisely metaphysical. As a consequence, the existing criteria for sustainable development are formulated, mainly in the categories of metaphysical project, i.e. society and the economy management according to the will of the ruling elite, further subordination of nature and society to the will of managers, solving the problems of one part of the world at the expense of other regions and countries, etc. As part of a dialectical type of rationality the sustainable society is a society of improving the public relations at all levels: economic, political, administrative, cultural, educational, spiritual, etc., improving the relations between regions and countries, and finaly, improving the relations globally in harmony and synergy between a human and nature. In this sense the concept of sustainable development is humanoriented and socially-oriented, directed to the future to preserve the social and cultural diversity and excellence, reducing the number of devastating conflicts, rather than to the local patching of present problem areas. Sustainable development of the society which is understood as a move towards perfection is a continuous, ongoing development of the society in which education contributes to the possibility of maintaining its integrity (sustainability), effecting the spiritual and moral priorities of the individual, the reality of shared intellectual and cultural space of society, both at the level of a separate state, and the global level.

The mechanisms of the stability of society can be understood as the perfection of social relations and lies in the fields of culture, morality, and education and training. As a result, the core of the sustainability of society is education, which forms the spiritual and moral values and the full range of practical knowledge and skills, including technology possessed by humanity today, that aim at the social relations perfection development. Education is one of the major social institutions on which the formation of the society of sustainable development as a society of committed relationship depends, because it lays 
the formation of a specialist along with general social behavioral patterns of a person, the aspiration to liberal chaos either to the perfection of a human and the society.

Here the leading role is played by the social and philosophical idea that the education system not only reflects the productive and social and political life of the society, but can be an important or even decisive factor of its change, its entering the path of sustainable development. Taking education as a factor in the adaptation of the society to the sustainable development should be the main methodological principle of the reviving strategy not only in Ukraine, but globally. Indeed, global education is a special metasystem, where the aims of the world education policy for the solution of global problems are defined and implemented, where specific ties and relations between states and their educational systems aimed at all-round empowerment of the most effective forms of implementation of tasks of the future are operated. National education affects a range of topical issues that arise within individual education systems in the specific social-economic areas of the world or large states. Problems of national education, in essence, do not go beyond the individual regions, and their solving is within the capabilities and competence of the educational policy of the state and the authorities of the region. Philosophical understanding of education comes from the fact that the core of education is a person acting as a liaison of all social changes. In relation to a person the task of education is the breading of certain personal qualities, moral guidelines, in order to give a person the opportunity to successfully adapt, to fit into the evolving structure of social and economic relations.

Subject to the criteria of adaptability in the analysis of education allows to answer the question: what constitutes a quality of education as a factor in the move of society towards sustainable development? If the education system successfully performs the adaptation function in relation to the individual, social group, the citizens of a particular country and, finally, the entire international community, such a system has a certain quality of education, aimed at the future transition to a society of sustainable development, understood as excellence [2].

Specifics of education. At the global level education is aimed at the adaptation of the society to the natural and social changes. Global level determines the specificity of a separate one (adaptation of separate states) and specifies, implements it in the individual (adaptation of a group, an individual). As the categories of global, separate and the individual are inseparable, and the difference in them is quite relative, they are mutually transformed into one another, and the purpose of adapting the system of education to an individual, a state and the society are interrelated and interdependent.

Modern specificity of education as a factor for sustainable development of the society is the axiologisation of education. The axiologisation of global education area means an updated priority of value grounds of the modern education. The axiologisation of global education reflects one of efforts of the society to adapt to rapid changes and to find the way to a new civilization (the society for sustainable development). The axiologisation of global education in the social move towards the sustainable development implies the need to move from the model of "Left Behind" education suited to the stage of unstable development of civilization, to a system model of advanced education which is adequate to the sustainable development goals and implements its principles.

The axiologisation of global education area can contribute to the intensive search for a new model of education, which would be consistent with the objectives of the future civilization, based on the fact that the main purpose of education system is the orientation into survival of all mankind. The required system goal of the axiologisation of global education area is the improvement and broadening of the scope of education and culture of people, which is the most important means of adaptation and survival of human in the world, that can make our development safe and sustainable. These are a social and cultural, a humanitarian and educational coping mechanisms that must displace and outstrip the most common now technocratic mechanism in which the main way out of the ecological crisis is seen only in the creation of ecological friendly techniques and technology [2].

Conclusions. The search of human civilization development strategy in the conditions of modern challenges imposes new quality requirements for the study of the place and the role of education in modern society. Thus, it is no coincidence that among modern research the number of works, devoted to the analysis of various aspects of education, increased significantly. 
The ontological feature of education as a factor for sustainable development of the society is that between the society and the education there is a dialectical interaction in the form of reciprocal social relations and, therefore, education is both a consequence and a cause in society adaptation processes. With the regard to the sustainable development of the society this means that education plays a pivotal role in shaping the world of sustainable development and the mainstreaming of social institutions for sustainable development. Education as one of the main factors for adaptation of society in modern conditions contributes to the formation of a new ideological horizon of an individual, which is reflected in the preservation of national values and sensitivity to the valuesof other cultures, makes it possible to adopt new social practices and use them in practice.

\section{REFERENCES}

1. Educating for Tomorrow’s World. Education Today: The Newsletter of UNESCO’s Education Sector, № 16, February - May 2006. Retrieved from http://unesdoc.unesco.org/images/0014/001444/144403E.pdf.

2. Parra-Luna, F. (2000). The Performance of Social Systems. NY: Springer Science + Business Media.

3. Young people, education, and sustainable development. Exploring principles, perspectives, and praxis. (2009). Wageningen Academic Publishers.

\section{Т. П. Голуб. Роль освіти в концепції сталого розвитку суспільства}

Стаття присвячена дослідженню явища освіти як фактора та засобу сталого розвитку сучасного суспільства. За сучасних реалій постійного виникнення суспільних проблем і криз концепція сталого розвитку вивчається та визначається багатьма вченими з усього світу як чи не єдина реальна перспектива стабільного розвитку людства. Спільною рисою розроблених підходів до визначення та впровадження у практику концепції сталого розвитку суспільства $є$ теорія, яка стверджує, що всі нагальні глобальні проблеми можуть бути вирішені за допомогою застосування інноваційних технологій у галузі економіки, менеджменту, екології, промисловості та ін. Криза освіти і зміни в соціальному і культурному житті людства тісно взаємопов'язані, вони є взаємозалежними. В цьому аспекті провідну роль відіграє соціально-філософська ідея про те, що система освіти не лише віддзеркалює економічне та соціально-політичне життя суспільства, але й може бути важливим або навіть вирішальним фактором його удосконалення, що дозволить здійснити еволюційний перехід у напряму сталого розвитку суспільства. Визнання освіти як основного фактору та засобу адаптації суспільства до сталого розвитку повинно бути головним методологічним принципом стратегії відродження в глобальному масштабі. Глобальна освіта $є$ спеціалізованою метасистемою, в якій цілі політики формування та діяльності світового освітнього простору у питаннях вирішення глобальних проблем визначають і створюють конкретні зв'язки між державами та їхніми освітніми системами, що спрямовані на всебічне розширення прав і можливостей найбільш ефективних форм реалізації діяльності, спрямованої на гармонізацію технологічного розвитку людства, суспільства та природи.

Ключові слова: сталий розвиток, освіта, світовий освітній простір, суспільство.

\section{Т. П. Голуб. Роль образования в концепции устойчивого развития общества}

Статья посвящена исследованию проблем образования как фактора и средства устойчивого развития современного общества. Концепция устойчивого развития исследуется многими учеными со всего мира, как, пожалуй, единственная реальная перспектива стабильного развития человечества в условиях современных проблем и кризисов. Кризис образования и изменения в социальной и культурной жизни человечества тесно взаимосвязаны. Здесь ведущую роль играют социально-философские идеи о том, что система образования не только отражает производственную и социально-политическую жизнь общества, но и может быть решающим фактором ее изменения в направлении устойчивого развития. Глобальный подход в образовании является особой метасистемой, в которой определяются цели политики мирового образования для решения глобальных проблем и реализуются конкретные связи и отношения между государствами и их образовательными системами, направленными на всестороннее развитие личности в гармонии с окружающим ее миром.

Ключевые слова: устойчивое развитие, образование, мировое образовательное пространство, общество. 